\title{
Reaction of faba bean genotypes to Rhizoctonia solani and resistance stability
}

\author{
Iraildes P Assunção ${ }^{1}$; Liliane D Nascimento후 Mércia F Ferreira² $^{2}$; Francisco J Oliveira ${ }^{2}$; Sami J \\ Michereff ${ }^{2}$; Gaus SA Lima ${ }^{1}$ \\ 'UFAL-CECA, BR 104 Norte, km 85, 57100-000 Rio Largo-AL; i_assuncao@hotmail.com; 2UFRPE, Dep ${ }^{\text {to }}$ Agronomia, Av. Dom Ma- \\ noel de Medeiros, s/n, 52171-900 Recife-PE; sami@depa.ufrpe.br
}

\begin{abstract}
The production of faba bean (Phaseolus lunatus) is limited due to the occurrence of Rhizoctonia canker, caused by the fungus Rhizoctonia solani. In order to select materials with potential for use in faba beans breeding programs and/or disease integrated management, 72 genotypes were evaluated and also stability of the disease resistance in relation to different pathogen isolates, inoculum densities and soil type. The seeds were sown in soil infested with the pathogen by the addition of colonized substrate (rice grains). The evaluation of genotypes was done after 15 days, using a note scale to discriminate the genotypes into five reaction classes. None of the 72 genotypes showed immunity to $R$. solani and only four genotypes (F-42, F-49, F-53 and F-58) behaved as highly resistant. The reactions presented by these genotypes varied according to the $R$. solani isolate, inoculum density and soil used. The genotype F-58 showed more stable resistance to pathogen isolates and inoculum densities. The genotype F-53 showed resistance stability in soils collected in different locations, remaining highly resistant in all situations. The genotype F-58 did not show high resistance to only one tested soil. Therefore, the genotypes F-58 and F-53 are promising sources of resistance to $R$. solani and should be indicated in areas infested by the pathogen.
\end{abstract}

Keywords: Phaseolus lunatus, Rhizoctonia canker, genetic resistance.

\section{RESUMO}

Reação de genótipos de fava a Rhizoctonia solani e estabilidade da resistência

A produção de fava (Phaseolus lunatus) é limitada pela ocorrência da rizoctoniose, causada pelo fungo Rhizoctonia solani. Visando selecionar materiais com potencial de utilização nos programas de melhoramento e/ou no manejo integrado da doença, foram avaliados 72 genótipos de fava e verificada a estabilidade da resistência em relação a diferentes isolados do patógeno, densidades de inóculo e tipos de solo. As sementes foram plantadas em solo infestado com o patógeno pela incorporação de substrato (grãos de arroz) colonizado. A avaliação dos genótipos foi realizada após 15 dias, com o auxílio de escala de notas, discriminando-os em cinco classes de reação. Nenhum dos 72 genótipos apresentou reação de imunidade a $R$. solani e apenas quatro genótipos (F-42, F-49, F-53 e F-58) comportaramse como altamente resistentes. As reações apresentadas por esses genótipos variaram conforme o isolado de $R$. solani, a densidade de inóculo e o solo utilizado. O genótipo F-58 evidenciou maior estabilidade na resistência aos isolados do patógeno e densidades de inóculo. O genótipo F-53 demonstrou estabilidade da resistência em solos coletados em diferentes locais, mantendo alta resistência em todas as situações. O genótipo F-58 não demonstrou alta resistência em somente um solo. Portanto, os genótipos F-58 e F-53 constituem fontes promissoras de resistência a $R$. solani e devem ser preferidas em campos infestados pelo patógeno.

Palavras-chave: Phaseolus lunatus, rizoctoniose, resistência genética.

(Recebido para publicação em 7 de julho de 2010; aceito em 29 de agosto de 2011) (Received on July 7, 2010; accepted on August 2011, 29)

$F^{a}$ aba bean (Phaseolus lunatus L.), also known as lima bean, broad bean or fava bean, is an important protein source in human and animal feeding worldwide and is an alternative income and food source for the population of the northeastern region of Brazil, where it is eaten either as ripe or unripe beans (Oliveira et al., 2004). However, this Fabaceae is low yielding, attributed to the fact it is produced on properties where adequate technologies are not adopted and diseases occur, that have hindered cropping and affected the quality of the beans and grains (Vieira,
1992).

Diseases caused by plant pathogens that live in the soil seriously hinder faba bean production. Rhizoctonia canker, caused by the Rhizoctonia solani Kühn fungus, is the main root disease of the faba bean in several countries (Salt, 1982; Baudoin, 2006; Infantino et al., 2006). In areas infested with $R$. solani the damage occurs mainly up to three weeks after planting and the characteristic symptoms of the disease are seed and root rot, canker in the hypocotyl and seedling damping-off in pre and post emergence (Lamari \&
Bernier, 1985; Omar, 1986).

Rhizoctonia solani control is extremely difficult because it lives in the soil and combines high saprophytic competitiveness with a wide host range (Ogoshi, 1987; Cubeta \& Vilgalys, 2000). To prevent the disease, the faba bean producers abandon the infected areas and migrate to uninfected fields, causing great economic losses because of the devaluation of the abandoned areas. Although there are no precise data on the percentage of faba bean production losses due to rhizoctonia canker incidence in areas infected by $R$. 
solani, the damage caused to seedlings pre and post emergence can completely affect production, as reported in other crops (Baker, 1970; Tu et al., 1996).

Using resistant genotypes is an important measure for integrated $R$. solani control in several crops (Panella \& Ruppel, 1996), but few advances have been reported in identifying resistant sources to this pathogen in faba bean (Infantino et al., 2006). In Canada, 304 genotypes were assessed but only five were identified with high resistance levels to $R$. solani, and some had the disadvantage of variable reaction depending on the isolate (Rashid \& Bernier, 1993).

In order to select faba bean genotypes with potential for use in future genetic breeding programs and/or integrated rhizoctonia canker management, the objectives of the present study were to assess resistance in faba bean genotypes to $R$. solani and ascertain the resistance stability at different inoculum densities of the pathogen and in soils from different locations.

\section{MATERIAL AND METHODS}

The resistance of faba bean genotypes to $R$. solani was assessed in three experiments. First, promising genotypes were selected and then the resistance stability was analyzed of these genotypes in relation to different pathogen inoculation densities and soil types. The three stages were carried out in a greenhouse, with temperature ranging from $22-34^{\circ} \mathrm{C}$ and $62-89 \%$ relative air humidity at the Academia de Ciencias Agrarias da Universidade Federal de Alagoas (UFAL) in Rio Largo, Alagoas state, Brazil.

Selecting promising genotypes - A collection of 72 faba bean genotypes, from various states of the Brazilian Northeast, kept in the germplasm banks at the Universidade Federal de Alagoas (30 accessions), Universidade Federal Rural de Pernambuco (32 accessions) and the Universidade Federal do Piaui (10 accessions), was assessed in relation to a $R$. solani isolate (CMM-1053; AG4 anastomose group), obtained from a faba bean plant with rhizoctonia canker symptoms. The $R$. solani inoculum was prepared in Erlenmeyer flasks containing $50 \mathrm{~g}$ autoclaved substrate $\left(120^{\circ} \mathrm{C}, 30\right.$ minutes, $\left.1 \mathrm{~atm}\right)$ consisting of rice grains diluted in $30 \mathrm{~mL}$ distilled water. Thirty-five $\mathrm{mm}$ diameter disks of fungus culture, previously cultured in potato dextrose agar (BDA) culture medium for seven days, were placed in each flask (Noronha et al., 1995). After 10 days incubation at $25^{\circ} \mathrm{C}$ and continuous light, the substrate colonized by the pathogen was placed in paper bags and placed to dry for 48 hours at $30^{\circ} \mathrm{C}$. The colonized, dry substrate was then ground in a blender for five minutes, sieved in 16 mesh and weighed according to the aliquot to be incorporated in the soil.

Soil collected in the municipality of Rio Largo (Table 1) sterilized in an autoclave $\left(120^{\circ} \mathrm{C}, 1 \mathrm{~atm}, 60\right.$ min, 2 consecutive days) was used in the experiment. Fifteen days after sterilization the soil $(1.5 \mathrm{~kg})$ was placed on a plastic tray $(30 \times 25 \times 4 \mathrm{~cm}, 2 \mathrm{~kg}$ capacity) and infested with $R$. solani at the density of $50 \mathrm{mg}$ colonized substrate per $\mathrm{kg}$ soil. The faba beans were planted immediately after infesting the soil by equidistant distribution of 10 seeds per tray. Before planting, the seeds were sanitized in a $1 \%$ sodium hypochlorite solution $(\mathrm{NaOCl})$ for two minutes, washed in running water and placed to dry for 45 minutes in an antiseptic chamber. All the faba bean genotypes had been assessed previously for seed germination percentage and levels greater than $85 \%$ were observed. The control consisted of planting the faba bean seeds in non-infested soil. A complete randomized design was used with four replications and each replication consisted of a tray with 20 planted seeds.

Rhizoctonia canker severity in the faba bean plants was assessed 15 days after sowing, using a score scale ranging from 0 to 4 (Noronha et al., 1995), where: $0=$ no symptoms, $1=$ hypocotyl with small lesions, $2=$ hypocotyl with big lesions, without constriction, $3=$ completely constricted hypocotyl, showing damping-off and $4=$ nongerminated seeds and/or non-emerged seedlings. The severity data were used to calculate the mean reaction of each genotype by the sum of the scores of each plant divided by the total number of plants assessed. This value was used to discriminate the genotypes in five reaction classes: $0=$ similar to immune (SI); $0.1-1.0=$ highly resistant (RH); 1.1-2.0= moderately resistant (MR); 2.1$3.0=$ susceptible $(\mathrm{SU}) ; 3.1-4.0=$ highly susceptible (HS).

Analysis of resistance stability to different $R$. solani isolates - The four faba bean genotypes (F-42, F-49, F-53 and F-58) that showed high resistance reaction (HR) to $R$. solani in the preliminary selection were assessed in relation to eight pathogen isolates, derived from cowpea (CMM-1062), fava (CMM-1053), beans (CMM-1064, CMM-1069), melon (CMM-1066, CMM-1067) and watermelon (CMM1065, CMM-1240). All the isolates were inoculated at the density of 50 $\mathrm{mg}$ colonized substrate per $\mathrm{kg}$ soil. The soil and the inoculum production procedures, pathogen inoculation, faba bean planting and disease assessment were the same as adopted for the selection of promising genotypes. A complete randomized experimental design was used in a $4 \times 8$ factorial scheme, with four faba bean genotypes and eight pathogens inoculums and densities, with four replications.

Analysis of the resistance stability to difference inoculum densities in Rhizoctonia solani - The four genotypes (F-42, F-49, F-53 and F-58) were assessed in relation to four inoculum densities $(50,100,150$ and $200 \mathrm{mg}$ substrate colonized per kg soil) of a faba $R$. solani isolate (CM1053). The soil and the inoculum production procedures, pathogen inoculation, faba bean planting and disease assessment were the same as adopted for the promising genotype selection. A complete randomized design was used, in a $4 \times 4$ factorial scheme, represented by four faba bean genotypes and four pathogen inoculum densities, with four replications.

Analysis of resistance stability to $R$. solani in soils from different locations - The four genotypes (F-42, F-49, F-53 and F-58) were assessed in relation to soils collected in nine locations in the state of Alagoas (Table 
1). The soils were sterilized and infected with a $R$. solani isolate (CMM-1053) at the density of $50 \mathrm{mg}$ colonized substrate per kilo of soil. The soil sterilization procedures, inoculum production, pathogen inoculation, faba bean planting and disease assessment were the same as those adopted for the promising genotype selection. A complete randomized block design was used in a 4 x 9 factorial scheme represented by four faba bean genotypes and nine soil types, with four replications. To characterize the possible factors involved in the soil suppressiveness and/or conduciveness to rhizoctonia canker induced in the faba bean genotypes, the mean values of the genotype reactions in the different soils were compared with the values of the soil chemical variables, by the Pearson correlation analysis at the level of 5\% probability.

\section{RESULTS AND DISCUSSION}

None of the faba bean genotypes presented reaction similar to immunity to $R$. solani and only four (F-42, F-49, F-53 and F-58) performed as highly resistant. Most of the genotypes (72.2\%) were moderately resistant, while $18.1 \%$ were susceptible and $4.2 \%$ highly susceptible (Figure 1). These results showed the difficulty in obtaining sources with high resistance levels to $R$. solani in faba bean genotypes, probably because of the pathogenesis process that results from the high aggressiveness of the pathogen to the host due to nonspecific infection mechanisms (Weinhold \& Sinclair, 1996).

The four highly resistant genotypes (F-42, F-49, F-53 and F-58) were assessed for resistance stability in relation to different $R$. solani isolates and inoculum densities in the soil and soils from different locations. All the $R$. solani isolates caused disease in faba bean (Table 2), although only one (CMM-1053) was obtained originally from the pathosystem studied. This flexibility of $R$. solani has been shown in other pathosystems and is characterized by the capacity to cause disease in different hosts, regardless of the host of origin or anastomose group (Baker, 1970; Ogoshi, 1987; Tu et al., 1996).

The reactions presented by the promising faba bean genotypes varied depending on the $R$. solani isolate (Table 2), and were similar to those reported in a study carried out in Canada (Rashid \& Bernier, 1993) and indicated that virulence varied among the pathogen isolates (Andrade et al., 2005). None of the promising genotypes presented high resistance reaction to all the pathogen isolates, although all the genotypes expressed high resistance to the CMM-1053 and CMM-1069 isolates. Genotype F-58 presented greater resistance stability to the $R$. solani isolates than the other genotypes, because it maintained the high resistance reaction to $63 \%$ of the isolates and moderate resistance to the other isolates $(37 \%)$. However, genotype $\mathrm{F}-42$ presented less resistance stability to the pathogen isolates with susceptibility reaction to $50 \%$ of the isolates.

When sown in soil infested with different densities of the $R$. solani CMM-1053 inoculum, genotypes F-42, $\mathrm{F}-53$ and $\mathrm{F}-58$ presented high resistance reaction to the pathogen at the $50 \mathrm{mg}$ $\mathrm{kg}^{-1}$ soil inoculum density (Figure 2 ) and were similar to that observed in the preliminary selection with the same inoculum density. However, at this inoculum density genotype F-49 performed as moderately resistant, changing reaction compared to the preliminary selection. At the $100 \mathrm{mg} \mathrm{kg}^{-1}$ inoculum density in the soil, genotype F-58 remained highly resistant, because the others performed as moderately resistant. At the density of $150 \mathrm{mg} \mathrm{kg}^{-1}$ soil, all the genotypes performed as moderately resistant and the same was observed at the $200 \mathrm{mg} \mathrm{kg}^{-1}$ soil density, except for genotype F-49, that presented the susceptibility reaction (Figure 2). Therefore genotype F-58 was superior for resistance stability to $R$. solani at different inoculum densities, while genotypes F-42 and F-53 presented intermediate performance and genotype F-49 showed low resistance stability at the highest inoculum density.

The resistance stability shown by some faba bean genotypes in relation to different $R$. solani inoculum densities in the soil was extremely important, because in studies involving this pathogen in other fabaceae such as

Table 1. Chemical characteristics of soils from state of Alagoas used in study of reaction of faba bean genotypes to Rhizoctonia solani in greenhouse (características químicas ${ }^{1}$ dos solos do estado de Alagoas utilizados no estudo da reação de genótipos de fava a Rhizoctonia solani sob condições de casa de vegetação). Rio Largo, UFAL, 2009.

\begin{tabular}{|c|c|c|c|c|c|c|c|c|c|c|}
\hline \multirow{2}{*}{ Municipality/local } & \multirow{2}{*}{ pH } & \multirow{2}{*}{ MO (\%) } & $\mathbf{P}$ & $\mathbf{K}$ & $\mathrm{Ca}+\mathrm{Mg}$ & Al & $\mathrm{Fe}$ & $\mathbf{C u}$ & $\overline{Z n}$ & Mn \\
\hline & & & \multicolumn{2}{|c|}{ (ppm) } & \multicolumn{2}{|c|}{$\left(\mathrm{meq} 100 \mathrm{~mL}^{-1}\right)$} & \multicolumn{4}{|c|}{ (ppm) } \\
\hline Arapiraca & 6.0 & 1.9 & 170 & 245 & 5.9 & 0.03 & 60.4 & 4.2 & 9.4 & 20.3 \\
\hline Branquinha & 6.9 & 1.3 & 82 & 182 & 5.2 & 0.02 & 183.7 & 2.3 & 2.3 & 31.6 \\
\hline Igaci I & 7.2 & 1.2 & 50 & 122 & 6.7 & 0.01 & 23.4 & 5.8 & 4.8 & 82.0 \\
\hline Igaci II & 7.2 & 1.3 & 53 & 430 & 4.8 & 0.00 & 15.5 & 5.9 & 5.2 & 139.0 \\
\hline Messias & 7.3 & 1.3 & 180 & 164 & 6.9 & 0.00 & 187.7 & 13.2 & 61.1 & 25.6 \\
\hline Murici & 6.7 & 1.6 & 129 & 247 & 6.3 & 0.02 & 543.2 & 10.5 & 9.6 & 77.0 \\
\hline Rio Largo & 6.1 & 3.0 & 199 & 190 & 7.7 & 0.03 & 151.2 & 2.8 & 6.8 & 23.7 \\
\hline São Miguel dos Campos & 5.8 & 1.5 & 12 & 70 & 5.2 & 0.05 & 54.0 & 3.2 & 3.4 & 8.1 \\
\hline União dos Palmares & 6.0 & 1.5 & 112 & 105 & 4.7 & 0.04 & 92.2 & 3.5 & 4.9 & 81.5 \\
\hline
\end{tabular}

${ }^{1}$ Analyzed by Embrapa (1997) (analisadas conforme Embrapa (1997)). 
Table 2. Reaction of faba bean genotypes to eight Rhizoctonia solani isolates in greenhouse (reação de genótipos de fava a oito isolados de Rhizoctonia solani sob condições de casa de vegetação). Rio Largo, UFAL, 2009.

\begin{tabular}{ccccc}
\hline \multirow{2}{*}{ Rhizoctonia solani isolate } & \multicolumn{4}{c}{ Genotype/reaction mean $^{\mathbf{1}}$} \\
\cline { 2 - 5 } & $\mathbf{F - 4 2}$ & $\mathbf{F - 4 9}$ & $\mathbf{F - 5 3}$ & $\mathbf{F - 5 8}$ \\
\hline CMM-1053 & $1,0^{2}$ & 0,9 & 0,9 & 0,8 \\
CMM-1062 & 2,5 & 1,9 & 1,9 & 1,9 \\
CMM-1064 & 2,8 & 2,2 & 2,2 & 0,4 \\
CMM-1065 & 2,7 & 2,0 & 1,8 & 1,5 \\
CMM-1066 & 2,0 & 0,9 & 0,9 & 0,4 \\
CMM-1067 & 1,2 & 0,9 & 0,9 & 1,8 \\
CMM-1069 & 0,6 & 0,2 & 0,8 & 0,1 \\
CMM-1240 & 2,2 & 0,7 & 1,5 & 0,5 \\
\hline
\end{tabular}

${ }^{1}$ Average of four replications, according to the disease scale from 0 to 4 (Noronha et al., 1995); ${ }^{2}$ Disease reaction classes: $0.0=$ similar to immune (SI); $0.1-1.0=$ highly resistant (HR); $1.1-2.0=$ moderately resistant $(\mathrm{MR}) ; 2.1-3.0=$ susceptible $(\mathrm{SU}) ; 3.1-4.0=$ highly susceptible ( ${ }^{1}$ média de quatro repetições, conforme escala de notas de 0 a 4 (Noronha et al., 1995); ${ }^{2}$ Classe de reação da doença: $0=$ semelhante à imune (SI); $0,1-1,0=$ altamente resistente (AR); 1,1-2,0= medianamente resistente (MR); 2,1-3,0= suscetível (SU); 3,1-4,0= altamente suscetível (AS)).

Table 3. Reaction of faba bean genotypes to Rhizoctonia solani (CMM-1053 isolate) in nine soils in greenhouse (reação de genótipos de fava a Rhizoctonia solani (isolado CMM-1053) em nove solos sob condições de casa de vegetação). Rio Largo, UFAL, 2009.

\begin{tabular}{lcccc}
\hline \multirow{2}{*}{ Soil (code) } & \multicolumn{4}{c}{ Genotype/reaction mean $^{\mathbf{1}}$} \\
\cline { 2 - 5 } & F-42 & F-49 & F-53 & F-58 \\
\hline Arapiraca & $1,2^{2}$ & 0,8 & 1,0 & 1,0 \\
Branquinha & 0,9 & 1,0 & 0,8 & 0,8 \\
Igaci I & 2,3 & 2,2 & 1,0 & 0,8 \\
Igaci II & 0,9 & 0,9 & 1,0 & 1,0 \\
Messias & 4,0 & 2,3 & 0,8 & 1,3 \\
Murici & 1,2 & 2,2 & 1,0 & 0,8 \\
Rio Largo & 0,6 & 0,8 & 0,9 & 0,9 \\
São Miguel dos Campos & 1,7 & 1,4 & 1,0 & 0,9 \\
União dos Palmares & 1,5 & 2,7 & 0,5 & 0,9 \\
\hline
\end{tabular}

${ }^{1}$ Average of four replications, according to the disease scale from 0 to 4 (Noronha et al., 1995); ${ }^{2}$ Disease reaction classes: $0.0=$ similar to immune (SI); $0.1-1.0=$ highly resistant (HR); 1.1-2.0= moderately resistant (MR); 2.1-3.0= susceptible (SU); 3.1-4.0= highly susceptible (média de quatro repetições, conforme escala de notas de 0 a 4 (Noronha et al., 1995); ${ }^{2}$ Classe de reação da doença: $0=$ semelhante à imune $(\mathrm{SI}) ; 0,1-1,0=$ altamente resistente $(\mathrm{AR}) ; 1,1-2,0=$ medianamente resistente (MR); 2,1-3,0= suscetível (SU); 3,1-4,0= altamente suscetível (AS)).

common bean (Phillips, 1989; Michereff Filho et al., 1996) and soybean (Cardoso et al., 1978), the disease intensity was proportional to the increase in the inoculum density.

The influence of the soil was evident on the reaction of most of the promising genotypes (Table 3 ) in the assessment of resistance stability to $R$. solani in soils collected from different locations of Alagoas state. In the soil from Rio Largo, used in the preliminary selection and in the soils from Igaci, Messias, Murici and União. Genotype F-58 presented good resistance stability in relation to the soils and it did not perform as highly resistant only in the Messias soil. Genotype 53 was outstanding for resistance stability to $R$. solani in the soils, maintaining the high resistance reaction regardless of the soil considered.

The pathogenic performance of $R$. solani has been linked to biotic and abiotic edaphic factors resulting in differences between soils regarding suppressiveness or conduciveness to rhizoctonia canker (Michereff Filho et al., 1996). Microbiological analyses were not made because the sterilized soils were used in the present study. However, the chemical characteristics of the soils showed significant influence on the severity levels of rhizoctonia canker in genotypes F-42 and F-58. In the first genotype there was positive correlation $(p \geq 0.05)$ of the disease levels with copper $(r=0.70)$ and zinc $(r=0.85)$ contents while in the second genotype with the zinc content $(\mathrm{r}=$ $0.88)$. Significant correlations were not observed $(p \geq 0.05)$ among the disease severity levels of the disease and the soil chemical characteristics in the other genotypes.

The stability presented by genotype F-53 in the soils showed the possibility for use in different soils, regardless of the level of conduciveness to rhizoctonia canker. On the other hand, the instability of genotypes F-42 and F-49 in the different soils indicated that abiotic factors may have been determinant for this performance, although it was not possible to highlight one factor, or a set of factors, that would account for this in all the soils.

The results obtained in the present study indicated management options for faba bean rhizoctonia canker using resistant genotypes, especially genotypes F-53 and F-58, that could be used in fields subject to rhizoctonia canker because in epidemics of the disease, resulting from areas infested by the pathogen, the losses could be high if the genotype cropped did not have acceptable resistance levels to the pathogen.

As plant resistance is a critical factor 


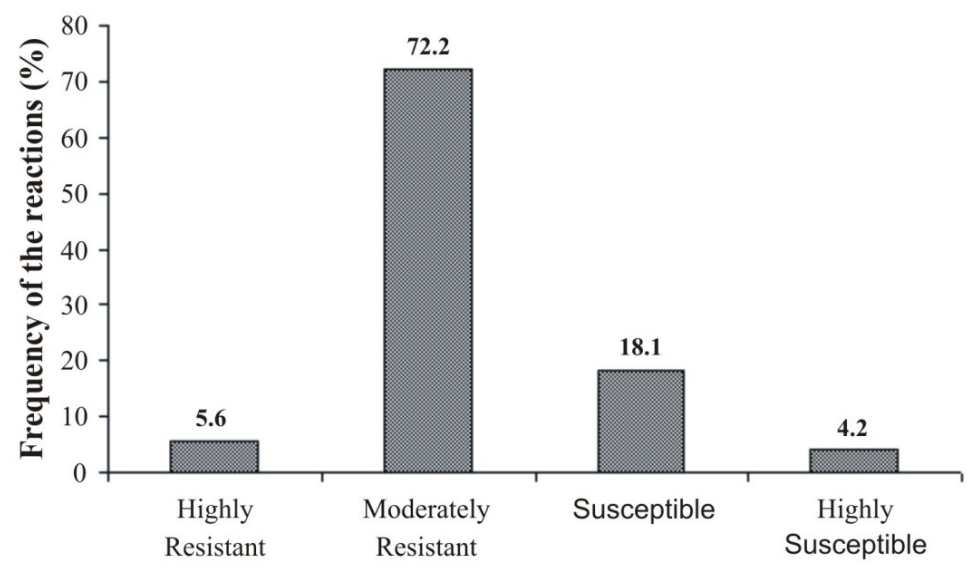

Type of reaction
Figure 1. Frequency of reaction classes of 72 faba bean genotypes to Rhizoctonia solani (CMM-1053 isolate) in greenhouse (freqüência de classes de reações de 72 genótipos de fava a Rhizoctonia solani (isolado CMM-1053) sob condições de casa de vegetação). Rio Largo, UFAL, 2009.

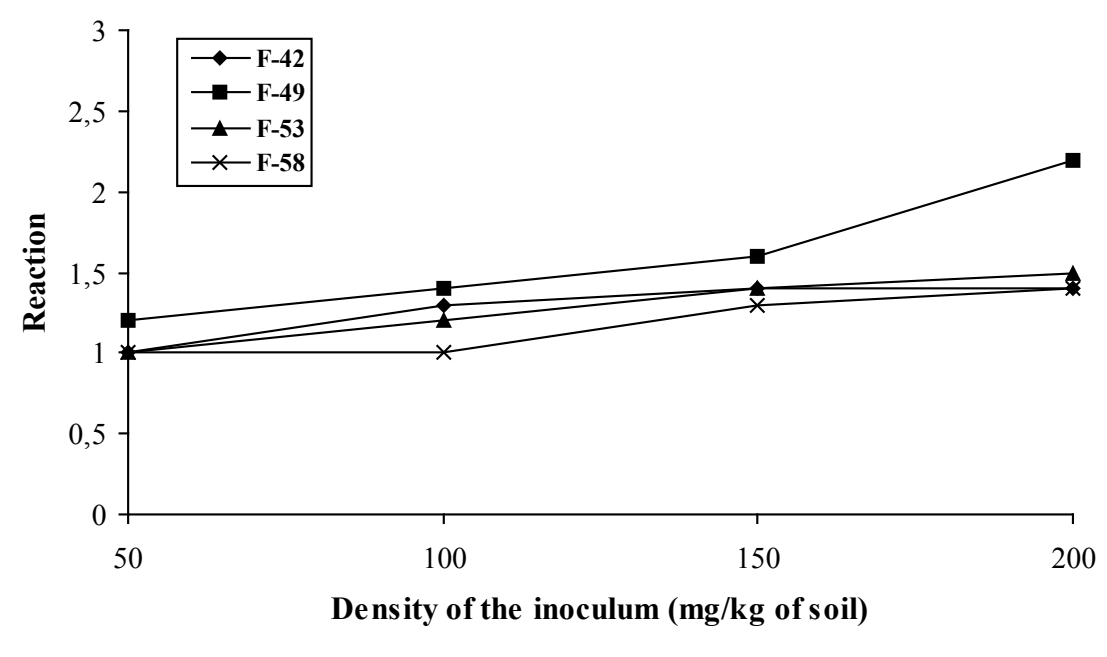

Figure 2. Reaction of faba bean genotypes ((F-42, F-49, F-53 and F-58) to four inoculum densities of Rhizoctonia solani (CMM-1053 isolate) in greenhouse, according to the disease scale from 0 to 4 (Noronha et al., 1995). Disease reaction classes: $0.0=$ similar to immune (SI); 0.1-1.0= highly resistant (HR); 1.1-2.0= moderately resistant (MR); 2.1-3.0= susceptible (SU); 3.1-4.0= highly susceptible (reação de genótipos de fava (F-42, F-49, F-53 e F-58) a quatro densidades de inóculo de Rhizoctonia solani (isolado CMM-1053) no solo sob condições de casa de vegetação, conforme escala de notas de 0 a 4 (Noronha et al., 1995). Classe de reação da doença: $0=$ semelhante à imune $(\mathrm{SI}) ; 0,1-1,0=$ altamente resistente (AR); 1,1-2,0= medianamente resistente (MR); 2,1-3,0= suscetível (SU); 3,1-4,0= altamente suscetível (AS)). Rio Largo, UFAL, 2009.

in faba bean root disease management (Infantino et al., 2006), when selecting resistance sources to rhizoctonia canker under Brazilian conditions it should be considered that virulence varies among the $R$. solani isolates, such as the indications in this study, so that susceptible faba bean genotypes are not considered resistant because not very virulent isolates were used or isolates with reduced ability to infect and colonize the plant.

It is emphasized that resistance alone is not sufficient for proper control of faba bean root diseases (Baudoin, 2006; Infantino et al., 2006). In this context, considering the difficulty in obtaining faba bean genotypes with high levels of resistance to rhizoctonia canker in different situations, such as reported in the present study, complementary management strategy should be adopted to maximize the durability of resistance to $R$. solani, including rotations of cropping areas, crops and faba bean genotypes, letting the sun shine on the soil before planting, increasing soil suppressiveness by incorporating organic matter to prevent damage to the plants during crop management and destroying crop remains.

\section{ACKNOWLEDGEMENTS}

The authors thank the coordinator of the faba bean germplasm banks at the Universidade Federal de Alagoas, the Universidade Federal de Pernambuco and the Universidade Federal do Piauí, for donating the seeds of some genotypes used in the experiments and the CNPq for the research productivity grants awarded to SA Lima and SJ Michereff.

\section{REFERENCES}

ANDRADE DEGT; SILVA CFB; SILVA LGC; MICHEREFF SJ; SALES JÚNIOR R; ASSIS TC. 2005. Influência da densidade do inóculo e de isolados de Rhizoctonia solani na severidade da rizoctoniose do meloeiro. Caatinga 18: 164-168.

BAKER KF. 1970. Types of Rhizoctonia diseases and their occurrence. In: PARMETER JR JR (ed). Rhizoctonia solani: biology and pathology. Berkeley: University of California Press. p. 125-148.

BAUDOIN JP. 2006. Phaseolus lunatus L. In: BRINK M; GRUBBEN GJH; BELAY G. (eds) Plant resources of tropical Africa (Prota) 1: Cereals and pulses. Leiden: Backhuys Publishers. p. 141-146.

CARDOSO JE; HILDEBRANDT AC; GRAU CR. 1978. Relationship of concentration and age of inoculum of Rhizoctonia solani Kühn on pathogenicity to germinating soybean seeds. Fitopatologia Brasileira 3: 193-204.

CUBETAMA; VILGALYS R. 2000. Rhizoctonia. In: LEDERBERGJ. (ed) Encyclopedia of microbiology. San Diego: Academic Press. v.4, p.109-116.

EMBRAPA. 1997. Manual de métodos de análises de solo. 2. ed. Rio de Janeiro: EMBRAPACNPS. 212 p.

INFANTINO A; KHARRAT M; RICCIONI L; COYNE CJ; MCPHEE KE; GRÜNWALD 
NJ. 2006. Screening techniques and sources of resistance to root diseases in cool season food legumes. Euphytica 147: 201-221.

LAMARI L; BERNIER CC. 1993. Etiology of seedling blight and root rot of faba bean (Vicia $f a b a)$ in Manitoba. Canadian Journal of Plant Pathology 7: 139-145.

MICHEREFF FILHO M; MICHEREFF SJ; SILVA EB; ANDRADE DEGT; ANTUNES SOBRINHO S; NORONHA MA; MARIANO RLR. 1996. Influência de tipos de solo do Estado de Pernambuco na intensidade da doença induzida por Rhizoctoni solani em feijoeiro. Fitopatologia Brasileira 21: 19-25.

NORONHA MA; MICHEREFF SJ; MARIANO RLR. 1995. Efeito do tratamento de sementes de caupi com Bacillus subtilis no controle de Rhizoctonia solani. Fitopatologia Brasileira 20: 174-178.

OGOSHI A. 1987. Ecology and pathogenicity of anastomosis and intraspecific groups of Rhizoctonia solani Kühn. Annual Review of Phytopathology 25: 125-143.
OLIVEIRA AP; ALVES EU; ALVES AU; DORNELAS CSM; SILVA JA; PÔRTO ML; ALVES AV. 2004. Produção de feijão-fava em função do uso de doses de fósforo em um Neossolo Regolítico. Horticultura Brasileira 22: 543-546.

OMAR SAM, 1996. Pathological studies on root rot diseases of faba bean (Vicia faba). Faba Bean Information Service (FABIS) Newsletter 14: 34-37.

PANELLA L; RUPPEL EG. 1996. Availability of germplasm for resistance against Rhizoctonia spp. In: SNEH B; JABAJI-HARE S; NEATE S; DIJST G (eds) Rhizoctonia species: taxonomy, molecular biology, ecology, pathology and disease control. Dordrecht: Kluwer Academic Publishers. p. 515-527.

PHILLIPS AJL. 1989. Relationship of Rhizoctonia solani inoculum density to increase of hypocotyl rot and damping-off in dry beans. Canadian Journal of Microbiology 35: 11321140.

RASHID KY; BERNIER CC. 1993. Genetic diversity among isolates of Rhizoctonia solani and sources of resistance in Vicia faba. Canadian Journal of Plant Pathology 15: 23-28.

SALT GA. 1982. Factors affecting resistance to root rot and wilt diseases. In: HAWTIN GC; WEBB C. (eds) Faba bean improvement. Dordrect: Martinus Nijhoff Publishers.

TU CC; HSIEH TF.; CHANG YC. 1996. Vegetable diseases incited by Rhizoctonia spp. In: SNEH B; JABAJI-HARE S; NEATE S; DIJST G. (eds). Rhizoctonia species: taxonomy, molecular biology, ecology, pathology and disease control. Dordrecht: Kluwer. p.369-377.

VIEIRA RF. 1992. A cultura do feijão-fava. Informe Agropecuário 16: 30-37.

WEINHOLD AR; SINCLAIR JB. 1996. Rhizoctonia solani: penetration, colonization, and host response. In: SNEH B; JABAJIHARE S; NEATE S; DIJST G (eds) Rhizoctonia species: taxonomy, molecular biology, ecology, pathology and disease control. Dordrecht: Kluwer Academic Publishers. p. 163-174. 